\title{
Novel ion exchange resin-based combination drug-delivery system for treatment of gastro esophageal reflux diseases
}

\author{
Mangesh Ramesh Bhalekar*, Nitin Madhukar Kadam, Nilam Hindurao Patil, \\ Nitin Somnath Gawale, Ashwini Madgulkar
}

Department of Pharmaceutics, AISSMS College of Pharmacy, India

\begin{abstract}
The present study involves preparation and characterization of a combination tablet of ranitidine in immediate release form and domperidone in sustained release form, using ion exchange resins. Ranitidine lowers acid secretion, while domperidone release over a prolonged period improves gastric motility thus justifying this combination in gastro esophageal reflux diseases (GERD) and ensuring patient compliance. Drug loading was carried out by batch method \& resinates were characterized using FTIR, XRPD. Resinates were formulated as a combination tablet and evaluated for tablet properties \& in vitro drug release. Resinates provided sustained release of domperidone and immediate release of ranitidine. IR and X-ray studies indicate complexation of drug and resin along with monomolecular distribution of drugs in amorphous form in the resin matrix. The tablets of resinate combination showed good tablet properties. In-vitro drug release gave desired release profiles and ex-vivo drug absorption studies carried out by placing everted rat intestine in dissolution medium indicated statistically significant similarity in absorption from test and marketed formulation. The novelty of this study is that the retardation in release of domperidone from resinates is achieved by presence of weak resin in the formulation.
\end{abstract}

Uniterms: Drugs/delivery system. Ranitidine/tablets/immediate release. Domperidone/tablets/sustained release. Tablets/delivery system. Ion exchange resins/use/ drugs delivery system.

O presente estudo envolve a preparação e a caracterização de associação do comprimido de ranitidina de liberação imediata e domperidona de liberação prolongada, utilizando resinas de troca iônica. A ranitidina diminui a secreção ácida, enquanto a liberação prolongada de domperidona melhora a motilidade gástica, justificando, dessa forma, a associação em doenças de refluxo gastroesofágico (DRGE) e garantindo a adesão do paciente. A carga de fármaco foi efetuada pelo método em batelada e os resinatos, caracterizados utilizando-se FTIR e XRPD. Os resinatos foram formulados como comprimido da associação e avaliados com relação às propriedades dos comprimidos e liberação do fármaco in vitro. Os resinatos proporcionaram a liberação prolongada da domperidona e a liberação imediata da ranitidina. IV e estudos de difração de raios X indicaram a complexação do fármaco e da resina junto com a distribuição monomolecular dos fármacos, em estado amorfo, na matriz da resina. Os comprimidos da associação do resinato apresentaram boas propriedades. Obtiveram-se os perfis de liberação in vitro e os estudos de absorção dos fármacos ex vivo realizados com intestino de rato em meio de dissolução indicaram semelhança significativa na absorção entre as formulações teste e comercializada. A inovação do trabalho é que o retardamento da liberação da domperidona dos resinatos é atingido pela presença de resina fraca na formulação.

Unitermos: Fármacos/sistema de liberação. Ranitidina/comprimido/liberação imediata. Domperidona/ comprimido/liberação prolongada. Comprimidos/sistema de liberação. Resinas de troca inônica/uso/ liberação de fármacos.

\footnotetext{
*Correspondence: M. R.Bhalekar. Department of Pharmaceutics, AISSMS. College of Pharmacy, Kennedy Road, Pune - 411001, India. E-mail: mrb1570@rediffmail.com
} 


\section{INTRODUCTION}

Research over the past few years has revealed that ion exchange resins are equally suitable for drug delivery technologies, including controlled release, site-specific fast dissolving, iontophoretically-assisted transdermal, nasal, topical, and taste masked systems. (Borodkin et al.,1971). Literature review (Anand et al., 2001) A literature review (Anand et al., 2001) revealed that ion exchange resins have versatile properties as a drug delivery vehicle. Moreover, resin characteristics such as acid or base strength, porosity, degree of cross linkage and particle size can be chosen from among the many available ion exchange resins to achieve the intended purpose (Vimaladevi et al., 2001). Combination products have the advantages of combination therapy besides reducing the complexity of the dosage regimen. Thus, combination therapy, if used optimally, has the advantages of increased efficacy and improved clinical effectiveness, broadening the array of therapeutic options, offering customization of the treatment to suit specific patient needs, enhanced patient adherence and reduction in cost of administration. (Wetheimer et al., 2002). Gastro esophageal reflux disease (GERD), reflux esophagitis, Peptic ulcer, gastric ulcer and other gastric acid-related disorders have pathogenesis related to reduced gastric motility and release of excessive gastric acid. GERD and gastric ulcer have been successfully treated with a range of gastric acid inhibitors, such as ranitidine, which are acid suppressing agents. Stimulation of gastric motility has been proposed to accelerate the healing of gastric ulcer and prokinetic agents such as domperidone are known to enhance gastrointestinal motility and prevent duodenogastric reflux. The aim of combining two or more drugs with complementary modes of action using ion exchange resins is to produce the desired release pattern and therapeutic benefits along with the advantage of reducing the complexity of the dosage regimen thus leading to patient compliance (Norris et al., 2005). In the present study, sustained release of domperidone was achieved by complexing with Indion 244 while the immediate release form of ranitidine hydrochloride was prepared by complexing with Indion 294. In vitro drug release from resinates was studied. Resinates were formulated into combination tablets and tablets were evaluated for hardness, thickness, friability, weight variation \& in-vitro drug release. An everted rat intestine model was employed for studying ex-vivo absorption and was compared with marketed preparation.

\section{EXPERIMENTAL}

\section{Material}

Ranitidine $\mathrm{HCl}$ was a gift from Wockhardt Pharma Ltd. Domperidone was from BURGEON Pharmaceuticals Pvt. Ltd.. Indion 244, Indion 294 were provided by Ion exchange India Ltd. Ranitidine HCL and domperidone were analyzed by Jasco V-530 UV/ VIS spectrophotometer. Resinates were evaluated by Jasco FT/IR-460.

\section{Methods}

The ranitidine \& domperidone were simultaneously estimated by simultaneous equation method spectrophotometricaly at $326 \mathrm{~nm} \& 287 \mathrm{~nm}$ using Jasco V-530 UV/ VIS Spectrophotometer.

Drug loading was carried out by batch method described elsewhere in the literature. (Vimaladevi et al., 2001; Plaizier et al., 1992).

The weak cation exchange resin Indion 234 was selected for binding ranitidine as ranitidine is a basic drug and is needed in immediate release form, whereas Indion 244, a strong cation exchange resin, was chosen to produce sustained release resinates of domperidone, again a basic drug. Both the drugs ranitidine hydrochloride $\&$ domperidone (100 $\mathrm{mg}$ each) were separately added to $100 \mathrm{~mL}$ of deionised water, and Indion 294 \& Indion 244 (100 mg each), respectively was placed into the solutions and stirred for four hours on a mechanical stirrer. The solutions were filtered and the amount of drug remaining in the filtrate was determined spectrophotometrically.

The amount of drug adsorbed was determined by the difference between the amount of drug present in stock solution and amount remaining in filtrate at the end of stirring.

Evaluation of physical properties of resins and
resonates (Lordi et al., 1991)
Different physical parameters of resinates including

TABLE I - Properties of Indion 244 and Indion 294

\begin{tabular}{|c|c|c|c|}
\hline Resin & Functionality & Matrix & Ion exchange capacity \\
\hline Indion 244 & $-\mathrm{SO}_{3} \mathrm{H}$ & Cross linked polystyrene $\mathrm{H}^{+}$ & $4.5 \mathrm{meq} / \mathrm{grygm}$ \\
\hline Indion 294 & $-\mathrm{COOH}$ & Cross linked polyacrylic $\mathrm{K}^{+}$ & NA \\
\hline
\end{tabular}


shape, flow properties, bulk density, tap density and packing ability were determined.

\section{Characterization of resin and resinates}

The FT-IR studies were carried out using a Jasco FT/ IR-460. The X-ray diffraction studies were carried on a Phillips analytical X-ray BV(PW 1710) device using cu anode $40 \mathrm{kv}$ voltage and 30 ma current.

\section{In-vitro drug release from resinates:}

Resinates of ranitidine hydrochloride with Indion 294, and domperidone with Indion 244, were subjected to in-vitro dissolution studies using an USP type II apparatus at $100 \mathrm{rpm}$. The dissolution medium was $900 \mathrm{ml} 0.1 \mathrm{~N}$ $\mathrm{HCl}$ at $37 \pm 0.5^{\circ} \mathrm{C}$.

\section{In-vitro drug release from combination of resinates:}

Resinates of ranitidine hydrochloride and domperidone, equivalent to their doses, were combined together. The combination of resinates were then subjected to invitro dissolution studies using an USP type II apparatus at $100 \mathrm{rpm}$. The dissolution medium was $900 \mathrm{ml} 0.1 \mathrm{~N}$ $\mathrm{HCl}$ at $37 \pm 0.5^{\circ} \mathrm{C}$.

\section{Formulation of combination tablets}

Resinates of ranitidine $\mathrm{HCl}$ (441.17 mg) and domperidone $(32.25 \mathrm{mg})$ equivalent to the therapeutic dose of free drug, were blended with mannitol $(71.38 \mathrm{mg})$ and granulated with gelatin solution (10\%). The granules were dried and blended with sodium starch glycolate $(6 \mathrm{mg})$, talc $(12 \mathrm{mg})$, magnesium stearate $(6 \mathrm{mg})$, methyl paraben (1.08), and propyl paraben $(0.12 \mathrm{mg})$ as excipients. Total weight of each tablet was kept at $600 \mathrm{mg}$. The tablets were compressed on a Karnavati Rimek press, using D tooling and a $12.5 \mathrm{~mm}$ flat punch with pressure adjusted to achieve hardness of $5 \mathrm{~kg} / \mathrm{cm}^{2}$.

\section{Evaluation of prepared tablets (Banker, Anderson, 1991)}

The physical properties of tablets such as general appearance, hardness, thickness, friability and weight variation, were determined as described elsewhere in the literature.

\section{In-vitro drug release profile of combination tablet and marketed tablets}

Prepared tablets and marketed tablets were subjected to in-vitro dissolution studies using an USP type II apparatus at $100 \mathrm{rpm}$. Dissolution medium was $900 \mathrm{ml} 0.1 \mathrm{~N}$ $\mathrm{HCl}$ at $37 \pm 0.5^{\circ} \mathrm{C}$.
Ex-vivo study for absorption through everted rat intestine (Dixon et al., 1977; Chowhan, 1977)

Ex-vivo study for absorption of drugs by the everted rat intestine technique was carried out using a modified perfusion apparatus.

The apparatus consist of ' $U$ ' shaped glass tubing having $1 \mathrm{~cm}$ inner diameter with cannulated cut on one arm of the ' $U$ ' tube. The volume capacity of apparatus was $25 \mathrm{~mL}$. The distance between two cannulated arms was $8 \mathrm{~cm}$ where the intestine was tied. After placement of intestine on the perfusion apparatus, the apparatus were dipped into the dissolution media in the dissolution pan and the dissolution study was performed under the abovementioned conditions.

From the prepared tablet, absorption of drugs through rat intestine was compared with marketed formulations of domperidone and ranitidine $\mathrm{HCl}$.

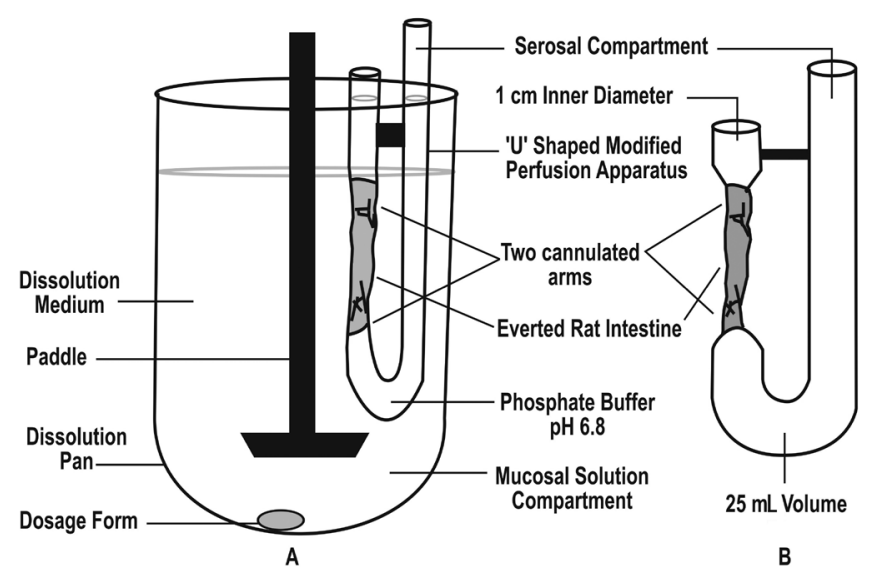

FIGURE 1 - [A] Modified perfusion apparatus in dissolution vessel. [B] Modified perfusion apparatus.

\section{RESULT AND DISCUSSION}

The batch process was used for drug loading. From preliminary experiments, 4 hours was found to be the optimum period for attainment of loading equilibrium of domperidone \& ranitidine. The drug loading was carried out at 1:1 drug resin ratio for both drug resin combinations. Indion 244 domperidone showed 48.44\% \& Indion 294 ranitidine showed $40.44 \%$ of drug content.

Table II summarizes the physical properties of resins and resinates. The shape of resinate affects the flow and packing properties \& was found to be irregular for Indion 244 resin and resinate. Angle of repose was found to lie between $20-30{ }^{\circ} \mathrm{C}$ thus exhibiting good flow properties. Bulk density less than $1.2 \mathrm{gm} / \mathrm{cm}^{3}$ exhibited good packing ability. Thus the results showed that resin and resinate 
TABLE II - Physical properties of resins and resinates

\begin{tabular}{lcccc}
\hline Parameter & Indion 244 Resin & Domperidone Resinate & Indion 294 Resin & Ranitidine Resinate \\
\hline Shape & Irregular & Irregular & Irregular & Irregular \\
Angle of repose & 26.56 & 24.22 & 25.34 & 27.21 \\
Bulk density & 0.681 & 0.550 & 0.625 & 0.584 \\
Tap density & 0.789 & 0.610 & 0.731 & 0.652 \\
Carr's index & 15.85 & 13.27 & 16.96 & 11.64 \\
Housner ratio & 1.15 & 0.98 & 1.16 & 0.98 \\
\hline
\end{tabular}

exhibit good flow properties. Carr's compressibility index i.e. \% compressibility, and Hausner ratio indicate the packing ability of powders.

When compressibility index ranges from 5 to 16 and the Hausner ratio approaches 1 the material has good flow property and packing ability.

\section{X-ray diffraction}

The X-ray diffraction pattern (Figure 2) for drugs [A \& D] contained a number of sharp peaks, while the resins [B \& E] showed a diffused peak or halo pattern, where as only a diffused peak was observed in X-ray powder diffraction patterns for the resinates regardless of drug loading.

According to this data, the molecular state of drugs $[A \& D]$ was crystalline, but that of resins $[B \& E]$ was amorphous. The molecular state of drugs prepared as drug resin complexes was changed from crystalline state to amorphous state. This shows that entrapped drug molecules are monomolecularly dispersed in resin beads (Pisal et al. 2004).

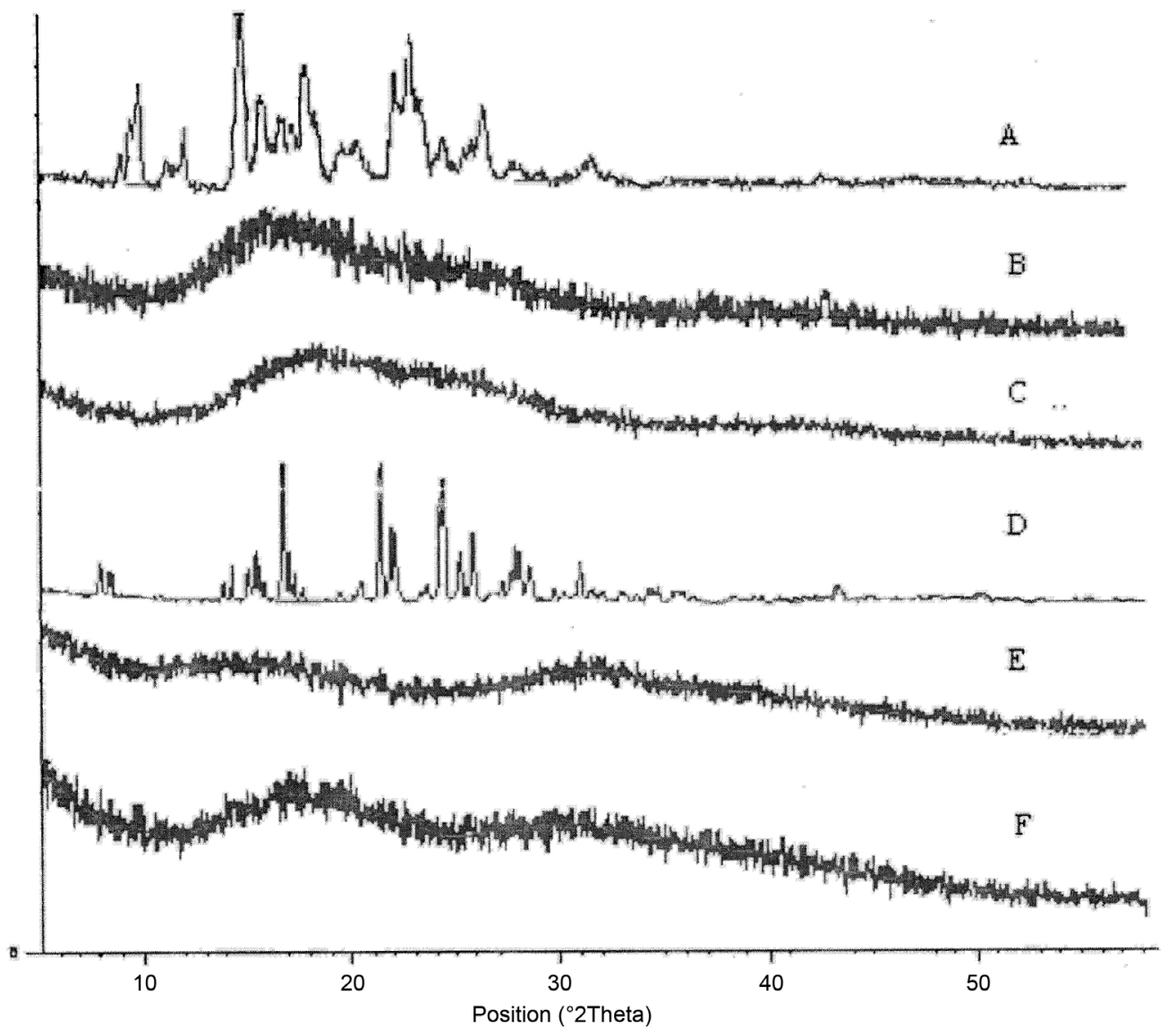

FIGURE 2 - X- ray powder diffraction pattern for A. Domperidone, B. Indion 244, C. Domperidone resinate, D. Ranitidine HCl, E. Indion 294, F. Ranitidine resinate. 


\section{FT-IR STUDIES}

The IR spectra for the drugs (Figure 3) [A\&D] shows peak at $3349 \mathrm{~cm}^{-1}$ corresponding to N-H stretching in a secondary amine. The absence of a peak at $3349 \mathrm{~cm}^{-1}$ in resinates $[\mathrm{C} \& \mathrm{~F}]$ confirms the complexation of the secondary amine group in the drugs $[\mathrm{A} \& \mathrm{D}]$ with resins $[\mathrm{B} \& \mathrm{E}]$.

The in-vitro dissolution profile (Table III) shows that about $43.41 \%$ of domperidone was released in $60 \mathrm{~min}$ from resinate, and about $97.83 \%$ of domperidone was released

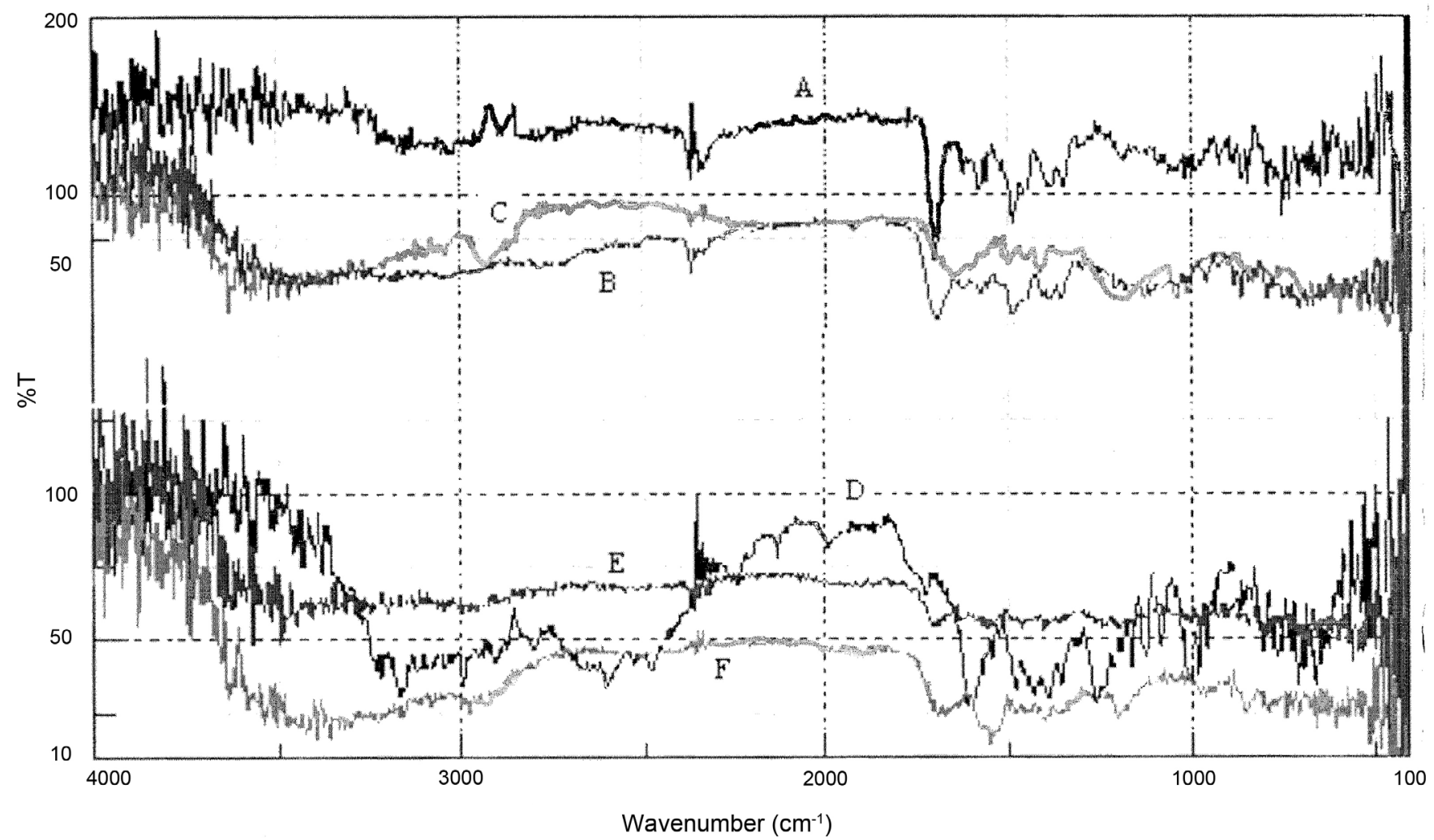

FIGURE 3 - Infrared spectra for A. Domperidone, B. Indion 244, C. Domperidone resinate, D. Ranitidine HCl, E. Indion 294, F. Ranitidine resinate.

TABLE III - In-vitro drug release profiles of ranitidine $\mathrm{HCl}$ and domperidone from resinates

\begin{tabular}{cccc}
\hline \% Drug Release For Ranitidine & \multicolumn{2}{c}{ \% Drug Release For Domperidone } \\
\hline Time (min) & \% Drug Release & Time (min) & \% Drug Release \\
\hline 5 & $39.42 \pm 0.28$ & 60 & $43.41 \pm 0.36$ \\
10 & $52.28 \pm 0.43$ & 120 & $53.30 \pm 0.24$ \\
20 & $61.27 \pm 0.25$ & 180 & $65.95 \pm 0.18$ \\
30 & $68.60 \pm 0.36$ & 240 & $67.31 \pm 0.22$ \\
40 & $71.99 \pm 0.41$ & 300 & $71.10 \pm 0.16$ \\
60 & $80.14 \pm 0.38$ & 360 & $73.41 \pm 0.29$ \\
75 & $87.70 \pm 0.29$ & 420 & $78.05 \pm 0.22$ \\
90 & $97.72 \pm 0.73$ & 480 & $84.17 \pm 0.41$ \\
-- & -- & 540 & $88.49 \pm 0.31$ \\
-- & -- & 600 & $93.52 \pm 0.33$ \\
-- & -- & 660 & $97.83 \pm 0.46$ \\
\hline
\end{tabular}

$($ Mean $\pm \mathrm{SD}, \mathrm{n}=3)$ 
at the end of $660 \mathrm{~min}$ from resinate. The resinate showed initial high release but could retard the drug release beyond $480 \mathrm{~min}$, therefore resinate of a 1:1 ratio showed potential to sustain the release of domperidone. The initial burst release may be attributed to lower particle size of resinate. (Borodkin et al., 1991). The ranitidine release from ranitidine resinate was found to be $97.72 \%$ in $90 \mathrm{~min}$.

A difference was observed between domperidone release from individual domperidone resinate \& combination with ranitidine resinate (Figure 4), where the release was retarded from combination. Similar observations are reported in the literature (Hughes, 2002)

This can be explained as follows, after complete release of ranitidine from resinate, the weak resin was available as unloaded resin as it is experimentally demonstrated that the drug release is retarded in the presence of unloaded resin.

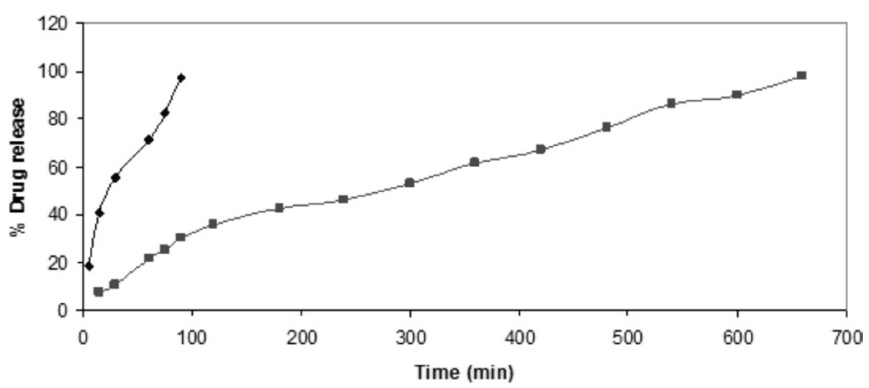

FIGURE 4- In-vitro ranitidine \& domperidone release from combination of resinates. $\downarrow \%$ release of ranitidine; $\%$ release of domperidone.

TABLE IV - Evaluation of prepared tablets

\begin{tabular}{cccc}
\hline $\begin{array}{c}\text { Hardness } \\
\mathrm{kg} / \mathrm{cm}^{2}\end{array}$ & $\begin{array}{c}\text { Thickness } \\
(\mathrm{mm})\end{array}$ & $\begin{array}{c}\text { Weight } \\
\text { uniformity }+ \\
(\mathrm{mg})\end{array}$ & \% Friability \\
\hline $5 \pm 0.25$ & 4.49 & $600 \pm 0.5$ & $0.7 \pm 0.43$ \\
\hline$($ Mean $\pm \mathrm{SD}, \mathrm{n}=3)$ & & &
\end{tabular}

\section{Assay of prepared tablets}

TABLE V - Assay analysis of prepared tablets

\begin{tabular}{lcccccc}
\hline Sr.No. & \multicolumn{2}{c}{$\begin{array}{c}\text { Label claim } \\
(\mu \mathrm{g} / \mathrm{mL})\end{array}$} & \multicolumn{2}{c}{$\begin{array}{c}\text { Amount found } \\
(\mu \mathrm{g} / \mathrm{mL})\end{array}$} & \multicolumn{2}{c}{$\begin{array}{c}\text { \% of label } \\
\text { claim }\end{array}$} \\
\hline & RAN & DOM & RAN & DOM & RAN & DOM \\
1 & 5 & 0.2 & 5.02 & 0.199 & 100.4 & 99.5 \\
2 & 5 & 0.2 & 4.93 & 0.198 & 98.8 & 98.6 \\
3 & 5 & 0.2 & 4.91 & 0.199 & 99.4 & 99.5 \\
4 & 5 & 0.2 & 5.01 & 0.202 & 100.2 & 101 \\
5 & 5 & 0.2 & 4.99 & 0.201 & 98.8 & 100.5 \\
\hline
\end{tabular}

\section{In-vitro drug release profile of combination tablet and marketed tablet}
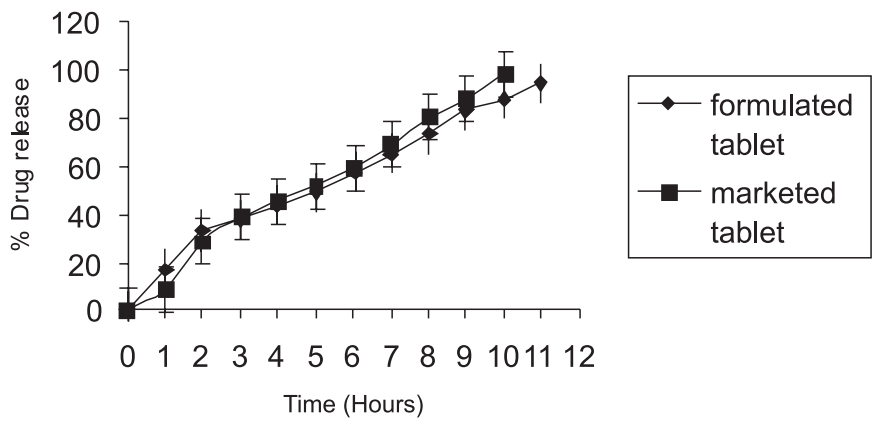

FIGURE 5 - In-vitro dissolution for domperidone from formulated and marketed tablet. Formulated tablet; Marketed tablet

The results show that the formulated tablet released $94.05 \%$ domperidone in 11 hours while the marketed tablet showed $98.24 \%$ domperidone release in 10 hours (Figure 5). Thus, the formulated tablet showed better sustained release of domperidone than the marketed tablet. The $\mathrm{f}_{2}$ value of the domperidone release from the combination tablet was found to be 83 , comparable to the marketed tablet, showing that the formulated tablet had a similar release profile as that of the marketed tablet.

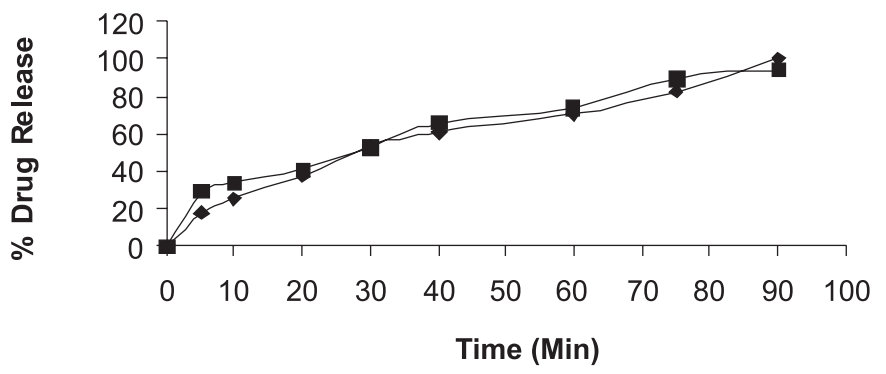

FIGURE 6 - In-vitro dissolution for ranitidine $\mathrm{HCl}$ from formulated and marketed tablet. Formulated tablet; - Marketed tablet.

In the case of ranitidine hydrochloride formulated tablets, the release was $99.45 \%$ drug in 90 min while the marketed tablet showed $94.43 \%$ ranitidine hydrochloride release in $90 \mathrm{~min}$. Thus, there was no significant difference in release of ranitidine hydrochloride from formulated \& marketed tablets. The $\mathrm{f}_{2}$ value of the ranitidine release from the combination tablet was found to be 58.5, compared to the marketed tablet, showing that formulated tablet had a similar release profile as that of the marketed tablet. 
TABLE VI - Ex-vivo study for absorption through everted rat intestine

\begin{tabular}{lcccc}
\hline Time (h) & \multicolumn{4}{c}{ \% Drug Absorbed } \\
\cline { 2 - 5 } & \multicolumn{2}{c}{ From formulated tablet } & \multicolumn{2}{c}{ From marketed tablet } \\
\cline { 2 - 5 } & $\begin{array}{c}\text { Ranitidine } \\
\text { hydrochloride }\end{array}$ & Domperidone & $\begin{array}{c}\text { Ranitidine } \\
\text { hydrochloride }\end{array}$ & Domperidone \\
\hline 0.5 & $67.23 \pm 1.23$ & $24.56 \pm 0.68$ & $72.64 \pm 0.25$ & $15.20 \pm 0.49$ \\
1 & $73.44 \pm 0.67$ & $25.68 \pm 0.29$ & $77.50 \pm 0.65$ & $18.27 \pm 0.69$ \\
2 & $81.63 \pm 0.72$ & $26.36 \pm 0.89$ & $79.71 \pm 0.81$ & $27.34 \pm 0.83$ \\
3 & -- & $32.04 \pm 0.78$ & -- & $33.46 \pm 0.79$ \\
4 & -- & $36.83 \pm 0.64$ & -- & $36.66 \pm 0.91$ \\
5 & -- & $37.41 \pm 0.69$ & -- & $38.53 \pm 0.48$ \\
6 & -- & $37.88 \pm 0.73$ & -- & $41.16 \pm 0.77$ \\
7 & -- & $43.45 \pm 0.75$ & -- & $44.38 \pm 0.59$ \\
8 & -- & $49.37 \pm 0.71$ & -- & $49.58 \pm 0.82$ \\
\hline
\end{tabular}

$($ Mean $\pm \mathrm{SD}, \mathrm{n}=3)$

\section{Ex-vivo study for absorption through everted rat intestine}

Data presented in Table VI represents the amount of domperidone \& ranitidine transported across everted rat intestine, expressed as percent of amount of drugs released in-vitro over the time interval. Data suggest that there is no difference in ex-vivo drug absorption from marketed and prepared combination tablet.

The data was subjected to paired t test using Instat3.0 software. The mean of the differences between column A and column B was found not to differ significantly from zero. The one-tailed $\mathrm{P}$ value was 0.3041 , considered nonsignificant at a $95 \%$ confidence interval.

By applying statistical treatment to the above data it was concluded that absorption of ranitidine hydrochloride and domperidone from formulated $\&$ marketed tablets did not differ significantly from each other.

\section{CONCLUSION}

Gastric acid inhibitors such as ranitidine $\mathrm{HCl}$, and prokinetic agents such as domperidone, are known to enhance gastrointestinal motility and prevent duodenogastric reflux, and are widely used to treat gastro esophageal reflux diseases (GERDs). Hence, a combination of immediate release ranitidine and sustained release domperidone in a unit dosage form will be a useful therapeutic option, enhancing patient compatibility and therapeutic benefit.

Formulated tablet provided $\mathrm{pH}$ independent sustained release of domperidone, and fast release of ranitidine. Ex-vivo studies suggest that there is no difference in ex-vivo drug absorption from marketed and prepared combination tablet.

\section{REFERENCES}

ANAND, V.; KANDARAPU, R.; GARG, S. Ion-exchange resins: carrying drug delivery forward. Drug Discov. Today, v.6, n.17, p.905-913, 2001.

BANKER, G.; ANDERSON, N. Tablets. In : LACHMAN, L.; LIBERMAN, H. A.; KANIG, J. L. (Eds.). The theory and practice of industrial pharmacy. Bombay: Varghese Publishing House, 1991. p.293-303.

BORODKIN, S.; SUNDERBERG, D. P. Polycarboxylic acid ion exchange resin adsorbates for taste coverage in chewable tablets. J. Pharm. Sci., v.60, n.10, p.1523-1527, 1971.

BORODKIN, S. Ion exchange resin delivery systems. In: TARCHA, P. J. (Ed.). Polymers for drug delivery. Boca Raton: CRC Press, 1991. p.215-230.

CHOWHAN, Z. T.; AMRO, A. A. Everted rat intestinal sacs as an in vitro model for assessing absorptivity of new drugs. J. Pharm. Sci., v.66 n.9, p.1249-1253, 1977.

DIXON, C.; MIZEN, L. W. Absorption of amino penicillin from everted rat intestine. J. Physiol., v.269, n.3, p.549$559,1977$.

HUGHES, L. Controlled dissolution of active ingredients. US patent Appl 20020146384, 2002. 
LORDI, N. G. Sustained release dosage forms. In: LACHMAN, L.; LIBERMAN, H. A.; KANIG, J. L. (Eds.). The theory and practice of industrial pharmacy. Bombay: Varghese Publishing House, 1991. p.67-68.

NORRIS, D. A. Mechanisms of action of topical therapies and the rationale for combination therapy. J. Am. Acad. Dermatol., v.53, n.1, p.17-25, 2005.

PISAL, S.; ZAINNUDDIN, R.; NALAWADE, P.; MAHADIK, K.; KADAM, S. Molecular properties of ciprofloxacinindion 234 complexes. AAPS PharmSciTech., v.5, n.4, p.1-8, 2004.
PLAIZIER- VERCAMMEN, J. A. Investigation of the bioavailability of codeine from a cation exchange sulphonic acid 1. Effect of parameters. Int. J. Pharm., v.85, n.1-3, p.45-50, 1992.

VIMALADEVI, M.; KRISHNABABU, P. S. S. Ion exchange resinates as controlled release drug delivery systems. In: JAIN, N. K. (Eds.). Advances in controlled and novel drug delivery. 1.ed. New Delhi: CBS publishers and Distributors, 2001. p.290-305.

WETHEIMER, A. I.; MORRISON, A. Combination drugs: innovation in pharmacotherapy. $P \& T$, v.27, n.1, p.44-49, 2002.

Received for publication on $06^{\text {th }}$ August 2008 Accepted for publication on $27^{\text {th }}$ July 2009 